\title{
Impacts of the Bolsa Família Program on the labor market of Brazilian municipalities
}

\author{
Carlos Barbosa Correa Junior 1 \\ Leonardo Nelmi Trevisan 1 \\ Cristina Helena Pinto de Mello ${ }^{2}$ \\ 1 Pontifícia Universidade Católica de São Paulo / Programa de Estudos de Pós-Graduação em Administração, São Paulo / SP - \\ Brazil \\ ${ }^{2}$ Escola Superior de Propaganda e Marketing / Programa de Mestrado em Comportamento do consumidor, São Paulo / SP — \\ Brazil
}

The Bolsa Família Program (PBF) benefits 14 million Brazilian families, and is one of the most important conditional cash transfer programs in Brazil in recent years. This articles investigates the impacts of the PBF in the formal labor market of the 5,570 Brazilian municipalities, from 2004 to 2013 . The research used data from all Brazilian municipalities retrieved from the Cadastro Único (database of low-income families) of the Ministry of Social Development (MDS) and the Cadastro Central de Empresas (database of corporations) of the Brazilian Institute of Geography and Statistics (IBGE). The study adopted methods to estimate the ordinary least squares (OLS), and used panel data models as well as the dynamic models of Arellano and Bond (1991) in order to test hypotheses related to the association among the benefits from PBF, formal employment, and the total of salaries and other remunerations payed. The results indicate a positive association for the two hypotheses tested, in all three models applied.

Keywords: Bolsa Família Program; job market; income distribution.

\section{Impactos do Programa Bolsa Família no mercado de trabalho dos municípios brasileiros}

Beneficiando cerca de 14 milhões de famílias brasileiras, o Programa Bolsa Família (PBF) é um dos mais importantes programas brasileiros de transferência condicionada de renda dos últimos anos. A investigação dos impactos do PBF, no mercado de trabalho formal dos 5.570 municípios brasileiros, no período de 2004 a 2013, constitui o principal objetivo deste artigo. Usando dados totais de cada um dos municípios da União, obtidos no Cadastro Único do Ministério do Desenvolvimento Social (MDS) e no Cadastro Central de Empresas do Instituto Brasileiro de Geografia e Estatística (IBGE), métodos de estimação dos mínimos quadrados ordinários (MQO), modelos de dados em painel e modelos dinâmicos de Arellano e Bond (1991), testam-se as hipóteses da associação do benefício do PBF com a quantidade de pessoal ocupado assalariado formal e com o total dos salários e de outras remunerações. Nos três modelos utilizados, os resultados indicam associação positiva para as duas hipóteses testadas. Palavras-chave: Programa Bolsa Família; mercado de trabalho; distribuição de renda.

\section{Impactos del Programa Bolsa Familia en el mercado de trabajo de los municipios brasileños}

Al beneficiar a cerca de 14 millones de familias brasileñas, el Programa Bolsa Familia (PBF) es uno de los más importantes programas brasileños de transferencia monetaria condicionada de los últimos años. La investigación de los impactos del PBF, en el mercado de trabajo formal de los 5.570 municipios brasileños, en el período de 2004 a 2013, constituye el principal objetivo de este artículo. Con datos totales de cada uno de los municipios de la República, obtenidos del Registro Único del Ministerio de Desarrollo Social (MDS) y del Registro Central de Empresas del Instituto Brasileño de Geografía y Estadística (IBGE), métodos de estimación de los mínimos cuadrados ordinarios (MCO), modelos de datos en panel y modelos dinámicos de Arellano y Bond (1991), se prueban las hipótesis de la asociación del beneficio del PBF con la cantidad de personal ocupado asalariado formal y con el total de los salarios y de otras remuneraciones. En los tres modelos utilizados, los resultados indican una asociación positiva para las dos hipótesis probadas.

Palabras clave: Programa Bolsa Familia; mercado de trabajo; distribución de ingresos. 


\section{INTRODUCTION}

Among the questions researched in the Social Sciences, such as those aimed at studying the wealth growth of nations or those directed to the distribution of wealth and to the increase of the well-being of society, an essential third one is that which deals precisely with the interrelations between growth and income distribution. The connection between product expansion and social equity has challenged researchers for decades, without a consensus on their reciprocal causality.

Pontusson (2005) expresses the essence of the implicit debate in the mentioned interrelation. On the one hand, liberalists signal the problem of increasing public spending and its harmful effects on private investment, accusing such policies for producing market distortions, reducing productivity (Easterly \& Rebelo, 1993; Okun, 1975). On the other hand, defenders of interventionist policies point to the beneficial effects of this way of economic growth, whether in the increase of the domestic market or in the multiplier effect of income in times of economic crises (Barro, 1990, 1991; Lucas, 1988; Romer, 1986).

In the Brazilian case, it is possible to verify both the significant economic growth, for example, the one from 70s, of 129\% (according to the Brazilian Institute of Geography and Statistics - IBGE) and the significant increase in inequality over the period (according to IBGE). In the 80s, successive economic policies, alternating freezes, hyperinflation and low economic growth, concurring with the worsening of social inequality. In late 90s, "compensatory" public policies began to reverse the extreme inequality situation. Cash conditional transfers, such as Bolsa Escola (School Allowance), Bolsa Alimentação (Food Allowance), Ajuda Gás (Gas Allowance), Cartão Alimentação (Food Card), were intensified, and, in 2003, the Bolsa Família (Family Allowance) Program (PBF) comes, whose main objective is to unify these four programs (Soares \& Sátyro, 2009).

Published studies related to the PBF highlight its beneficial effects in terms of reducing poverty, increasing school attendance and reducing inequality (Bussmann \& Risco, 2012; Jacinto \& Tejada, 2009). However, PBF impact on the labor market and economic efficiency remains an open question.

This article associates the total transferred by the PBF in each of the 5,570 municipalities to local labor variables, specifically the amount formalized and the amount of wage received. For this, three different estimation methods are used: ordinary least squares (OLS), panel data models and Arellano and Bond model (1991). Significant coefficients of program impact on interest variables are found, based on administrative records of the Ministry of Social Development and Fight against Hunger (MDS) between the years 2004 and 2013. The results indicate the positive association for the 2 hypotheses tested, reinforcing previous studies that suggest that income transfers arising from the PBF can cause wage increases in a new market balance of the municipality.

\section{IMPACTS OF THE BOLSA FAMÍLIA (FAMILY ALLOWANCE) PROGRAM IN THE FORMAL LABOR MARKET}

According to Arretche (1995, p. 3), "the provision of social services, covering the most varied forms of individual and collective life risk has become a right ensured by the State to very expressive layers of the population of developed capitalist countries". Fleury (1994, p. 11) argues that "the analysis of the State intervention in social issued, through the so-called social policies, has the existence of a positive law relationship that is established between the citizen and his State as a corollary". This 
suggests that "state intervention through social policies, regulating and/or providing conditions for the maintenance and reproduction of a portion of the population, is considered an intrinsic function of the modern State, configuring patterns of social rights proper to each nation" (Fleury, 1994, p. 11).

Kerstenetzky (2011) argues that national social policies have maintained, from the 30 s until the 70s, a pattern linked to the economic development model in which the main target groups of social policies are urban workers and civil servants. With the Constitution of the Federative Republic of Brazil (CF, 1988), however, the Brazilian social assistance is now inserted in the social security scope, seeking to replace an inefficient national welfare by a public policy of social assistance and welfare promotion, integrating, alongside health and social security policies, the general system of social protection.

With the new CF (1988), the Brazilian State becomes the main responsible for improving the population quality of life: health care programs are being developed, such as the Unified Health System (SUS), and cash conditional transfers programs - Bolsa Escola (School Allowance), Bolsa Alimentação (Food Allowance), Ajuda Gás (Gas Allowance), Cartão Alimentação (Food Card) - in order to combat poverty and reduce social inequalities. In 2003, these cash conditional transfers programs were grouped into a single system, considered more efficient: PBF. According to Draibe (2009, p. 105), "among the key factors pointed out by analysts, design simplicity, implementation flexibility, operational agility, relatively low administrative costs are highlighted".

Studies that investigate the impacts of PBF on the labor market and aggregate product are consolidated (Barbosa \& Corseuil, 2014; T. Cavalcanti \& Corrêa, 2010; Foguel \& Barros, 2010; Ribas \& Soares, 2011; Tavares, 2010), with the proposition of new theories (D. M. Cavalcanti, Costa, Silva, \& Sampaio, 2016; Denes, Komatsu, \& Menezes, 2016; Nunes \& Mariano, 2015; Rands Barros, \& Athias, 2013). Likewise, studies on the relationship between the benefit of PBF and the labor market, which are generally based on the data analysis of the National Household Sample Survey (PNAD) or the Consumer Expenditure Survey (POF), are growing.

According to Foguel and Barros (2010), the cash conditional transfers programs in Brazil do not change the average number of hours worked by men, but increase their participation rate and lead to a drop in hours worked by women, without influencing their participation rate. The authors estimate the effects of cash conditional transfers programs on the labor supply of adult women and men using the municipalities panel continuously covered by the PNAD or the IBGE's Census in the period between 2001 and 2005. According to Oliveira and Soares (2012), except for specific demographic groups, such as women with children, the disincentive to work is very small or nonexistent. Brito and Kerstenetzky (2010) determine the effects of the PBF on the beneficiary's labor market using data from the Single Registry of 2008 and PNAD of 2006. Santos, Leichsenring, Menezes, and Mendesda-Silva (2017) analyzed the effect of the PBF on the formal employment of the poor portion of the population using data between 2008 and 2011 of the Single Resgitry combined with data from the Annual Social Information Report, concluding that the chances of PBF beneficiaries remaining in employment are higher than for non-beneficiaries.

Regarding informality, there are studies whose results suggest that the PBF increases the probability of substitution effect: changing formal to informal employment of its beneficiaries (Marinho \& Mendes, 2013) and those that indicate that the program has no impact on the occupational choice of beneficiaries between formal and informal employment (Barbosa \& Corseuil, 2014). 
International research also investigates the relationship between compensatory policies and the labor market (Asfaw, Davis, Dewbre, Handa, \& Winters, 2014; Kabber \& Waddington, 2015; Skoufia \& Di Maro, 2008). Some studies are looking for comparative processes in the South American reality, approaching the main characteristics of the cash conditional transfers programs and their impacts in the regional labor markets (Alzúa, Cruces, \& Ripani, 2012; Economic Commission for Latin America and the Caribbean \& International Labour Organization, 2015).

However, despite the content of the international surveys, as well as the national ones, the impacts of the PBF in relation to the formal labor market still remain a matter in discussion.

\section{METHOD AND DATA}

According to Jacinto and Tejada (2009), models regarding efficiency and equality encompass three characteristic lines of investigation: a) dualistic models and the inverted U hypothesis; b) Kuznets curve and growth models; and c) Kuznets curve and social choice. This study belongs to the third group, which incorporates theories of endogenous growth involving political elements of social choice. Thus, to achieve the main objective of this work, two hypotheses were tested:

- Hypothesis H1: The PBF benefit is positively associated with the amount of salaried employees employed in the municipality.

- Hypothesis H2: The BPF benefit is positively associated with the total wages and other remunerations in the municipality.

The research covered the econometric deductive model. The first part of the statistical analysis brings the formulation of the linear model of variables of first difference, year by year, with OLS estimators. This regression model is linear for the parameters and can be represented by the function $(1)^{1}$ :

$$
\Delta \mathrm{Y}_{\mathrm{i}}=\beta_{1}+\beta_{2} \Delta \mathrm{X}_{\mathrm{i}}+\mathrm{u}_{\mathrm{i}}
$$

The second and third parts of the statistical analysis bring panel data models. The second model can be represented by the function $(2)^{2}$, where the dependent variable is explained by a set of explanatory variables and an error term.

$$
\mathrm{Y}_{\mathrm{i}, \mathrm{t}}=\alpha_{0}+\beta_{1} \mathrm{X}_{1 \mathrm{i}, \mathrm{t}}+\beta_{\mathrm{n}} \mathrm{X}_{\mathrm{ni,t}}+\mathrm{u}_{\mathrm{i}, \mathrm{t}}
$$

Finally, observing that, in the regression analysis involving time series, the models can also include out-of-phase values, the third model contemplates a dynamic econometric analysis with out-of-phase

\footnotetext{
${ }^{1}$ Where: $\Delta \mathbf{Y}_{\mathrm{i}}$ represents the differences of the dependent variable, $\mathbf{i}$ represents the $\mathrm{i}^{\text {th }}$ cross-sectional unit, $\boldsymbol{\beta}_{1}$ and $\boldsymbol{\beta}_{2}$ represent the parameters to be estimated, $\Delta \mathbf{X}_{\mathbf{i}}$ represents the differences of the independent variable, e $\mathbf{u}_{\mathrm{i}}$ represents the independent error term.

${ }^{2}$ Where: $\mathbf{Y}_{\mathrm{it}}$ represents the $\mathrm{i}^{\text {th }}$ cross-sectional unit in the $\mathrm{t}^{\text {th }}$ time period, $\boldsymbol{\alpha}_{\mathbf{0}}$ and $\boldsymbol{\beta}_{1}, \ldots, \boldsymbol{\beta}_{\mathbf{n}}$ represent the parameters to be estimated, $\mathbf{X}_{1, \mathrm{it}}$ represents the first exogenous variable, referring to the $\mathrm{i}^{\text {th }}$ cross-sectional unit in the $\mathrm{t}^{\text {th }}$ time period, $\mathbf{X}_{\mathrm{n}, \mathrm{it}}$ represents the $\mathrm{n}^{\text {th }}$ exogenous variable, referring to the $\mathrm{i}^{\text {th }}$ cross-sectional unit in the $\mathrm{t}^{\text {th }}$ time period, and $\mathbf{u}_{\mathrm{it}}$ represents the $\mathrm{i}^{\text {th }}$ error term in the $\mathrm{t}^{\text {th }}$ time period.
} 
autoregressive data, with out-of-phase values of the dependent variable, according to function (3) where the dependent variable is explained by a set of explanatory variables and an error term.

$$
\mathrm{Y}_{\mathrm{it}}=\alpha_{0}+\beta_{1} \mathrm{X}_{1, \mathrm{it}}+\ldots+\beta_{\mathrm{n}} \mathrm{X}_{\mathrm{n}, \mathrm{it}}+\phi_{1} \mathrm{Y}_{\mathrm{it}-1}+\mathrm{u}_{\mathrm{i}, \mathrm{t}}
$$

This self-regressive model is based on the idea that the dependent variable is not adjusted immediately due to changes in the explanatory variables and that past values tend to influence their own future values. In this study, we use the generalized method of moments (GMM) estimators, developed by Arellano and Bond (1991), which allows obtaining reliable estimators in lagged panel data models.

As variables, the following are used for each of the 5,570 (N) municipalities: a) total values received from the PBF benefits by all families living in the municipality; b) total amount of families benefited by the PBF; c) total number of employed and salaried people and with a formal contract living in the municipality; d) total value of wages and other remuneration of the employed salaried people and with a formal contract living in the municipality; e) total value of the business units of employed and salaried people with a formal contract living in the municipality; and (f) the total annual gross domestic product (GDP) of the municipality, as shown in Table 1.

STUDY VARIABLE

$\begin{array}{cc}\text { Variables per municipality } & \text { Source } \\ \text { Total benefit of the PBF } & \text { Single Registry (MDS) } \\ \text { Amount of families benefited by PBF } & \text { Single Registry (MDS) } \\ \text { Annual municipal GDP } & \text { Central Register of Enterprises (IBGE) } \\ \text { Wages and other remuneration } & \text { Central Register of Enterprises (IBGE) } \\ \text { Employed and salaried people on the last day of the year } & \text { Central Register of Enterprises (IBGE) } \\ \text { Local units } & \text { Central Register of Enterprises (IBGE) }\end{array}$

Source: Elaborated by the authors.

The data are collected through the official governmental websites, thus, are considered a primary source from: a) IBGE, Directorate of Research, Methodology Coordination of Business Statistics, Registry and Classifications, Central Registry of Enterprises; and b) Single Registry, Social Information Matrix of the Ministry of Social Development (MDS), both referring to the years 2004 to 2013, with annual or monthly values accumulated annually.

\footnotetext{
${ }^{3}$ Where: $\mathbf{Y}_{\mathrm{it}} ; \mathbf{X}_{1, \mathrm{it}} ; \ldots ; \mathbf{X}_{\mathrm{n}, \mathrm{it}}$ and $\mathbf{u}_{\mathrm{it}}$ have the same interpretations of function (4). Besides that, $\boldsymbol{\alpha}_{\mathbf{0}} ; \boldsymbol{\beta}_{\mathbf{1}} ; \ldots ; \boldsymbol{\beta}_{\mathrm{n}}$ still represent the parameters to be estimated. The difference in this specification is that a new parameter $\varphi 1$ appears representing the autoregressive parameter that needs to be estimated and relates to the first lag of the variable $\mathbf{Y}_{\mathrm{it}}$, namely, $\mathbf{Y}_{\mathrm{it}-\mathrm{I}}$.
} 
The choice of empirical observation interval cut-off between the 2004 and 2013 is due to 3 reasons: a) in the 2002 and 2003, PBF was either in the implementation phase or in the initial phase of operation and it is understood that, at that stage, there could be behavioral family change reversed in the short term; b) starting in 2004, the perennial effects of the program are already reflected; and c) the completion of the collection in 2013 is due to the limited availability of data on formally employed people and wages at the date of the research

The choice of the number of people employed and the wage and the average remuneration are based only on the formal work, that is, people who work with a formal contract, has the objective of analyzing the evolution not only of employment and wages, but also of the formalization of the Brazilian economy.

The choice to use the total specific data of each of the 5,570 municipalities to the detriment of the data of the PNAD or IBGE Census, which have the individual or the families as unit, is justified by the suggestion of "searching for a new database to verify conclusions from previous studies" (King, Keohane, \& Verba, 1996, p. 27). Also because the purpose of the research is not about the individual or family behavior arising from the benefit of the program, but alternatively it evaluates the aggregate impact of the program. By using the total specific data of each of the municipalities of the Union rather than based on data from the PNAD or the IBGE Census, i.e., because it is not about the individual or family behavior arising from the benefit of the program, but, alternatively, to evaluate the aggregate impact of policies in the municipalities, this research allows the confrontation with the conclusions of previous studies, developed through the use of alternative databases. The data are collected directly from the official government agencies. Table 1 summarizes the total current values of the variables used.

TABLE 1 TOTAL ANNUAL CURRENT VALUES OF THE VARIABLES SURVEYED

\begin{tabular}{|ccccccc} 
Year & $\begin{array}{c}\text { PBF benefit, in } \\
\text { R\$ millions }\end{array}$ & $\begin{array}{c}\text { Amount of families benefited } \\
\text { by BFP, on a thousand } \\
\text { families }\end{array}$ & $\begin{array}{c}\text { GDP, in RS } \\
\text { billion }\end{array}$ & $\begin{array}{c}\text { Wages and other } \\
\text { remuneration, in R\$ } \\
\text { billion }\end{array}$ & $\begin{array}{c}\text { Salaried employed } \\
\text { people, in thousand } \\
\text { people }\end{array}$ & $\begin{array}{c}\text { Local } \\
\text { units, in } \\
\text { thousands }\end{array}$ \\
\hline 2004 & 3,792 & 6,572 & 1,941 & 398 & 31,138 & 5,929 \\
2005 & 5,692 & 8,700 & 2,147 & 453 & 33,092 & 6,248 \\
2006 & 7,525 & 10,966 & 2,369 & 547 & 34,998 & 4,764 \\
2007 & 8,965 & 11,043 & 2,691 & 616 & 37,641 & 4,904 \\
2008 & 10,607 & 10,558 & 3,187 & 716 & 39,456 & 5,120 \\
2009 & 12,455 & 12,371 & 3,239 & 800 & 41,348 & 5,393 \\
2010 & 14,373 & 12,778 & 3,990 & 929 & 44,141 & 5,704 \\
2011 & 17,358 & 12,851 & 4,146 & 1,065 & 46,399 & 5,723 \\
2012 & 21,157 & 13,902 & 4,390 & 1,211 & 47,510 & 5,814 \\
2013 & 24,890 & 14,086 & 5,316 & 1,320 & 47,665 & 5,846 \\
\hline
\end{tabular}

Source: Elaborated by the authors. 
Table 2 shows the descriptive statistics for the variable of total benefit of the PBF by municipality between the years of 2004 and 2013. It is observed that the average value of the benefit grew, on average, $23.2 \%$ per year (p.y.) in the period.

TABLE 2 DESCRIPTIVE STATISTICS FOR THE VARIABLE OF TOTAL BENEFIT OF THE PBF, CURRENT VALUES, IN R\$

\begin{tabular}{|rrrrrr}
\hline Year & \multicolumn{1}{c}{ Average } & \multicolumn{1}{c}{ Median } & Standard deviation & \multicolumn{1}{c}{ Minimum } & \multicolumn{1}{c}{ Maximum } \\
\hline 2004 & $685,427.52$ & $274,848.50$ & $1,985,023.77$ & 168.00 & $83,629,166.00$ \\
2005 & $1,023,681.12$ & $443,798.50$ & $2,784,547.98$ & 325.00 & $112,404,678.00$ \\
2006 & $1,352,383.42$ & $594,705.00$ & $3,574,349.73$ & 720.00 & $129,006,666.00$ \\
2007 & $1,611,340.69$ & $706,125.00$ & $4,392,482.73$ & $1,280.00$ & $151,772,106.00$ \\
2008 & $1,906,272.50$ & $823,372.00$ & $5,323,984.63$ & $1,134.00$ & $172,598,270.00$ \\
2009 & $2,238,444.02$ & $949,381.50$ & $6,453,458.76$ & 752.00 & $178,942,695.00$ \\
2010 & $2,582,695.93$ & $1,103,867.00$ & $7,170,577.59$ & 660.00 & $200,137,472.00$ \\
2011 & $3,119,206.63$ & $1,324,975.00$ & $9,038,200.23$ & 708.00 & $243,203,214.00$ \\
2012 & $3,801,751.07$ & $1,593,996.00$ & $10,874,276.25$ & $4,408.00$ & $317,886,792.00$ \\
2013 & $4,469,403.32$ & $1,878,116.00$ & $12,995,376.33$ & 620.00 & $430,243,182.00$ \\
\hline
\end{tabular}

Source: Elaborated by the authors.

Table 3 shows the descriptive statistics for the number of families benefited by the PBF variable by municipality between the years of 2004 and 2013. It is observed that the number of families benefited by the PBF grew, on average, $8.8 \%$ p.y. in the period and there was a small decrease in the number of families benefited in 2008 .

\section{TABLE 3 DESCRIPTIVE STATISTICS OF THE VARIABLE NUMBER OF FAMILIES BENEFITED BY THE PBF}

\begin{tabular}{|c|c|c|c|c|c|}
\hline Year & Average & Median & Standard deviation & Minimum & Maximum \\
\hline 2004 & 1,188 & 518 & 3,666 & 2 & 165,991 \\
\hline 2005 & 1,565 & 692 & 4,253 & 1 & 167,038 \\
\hline 2006 & 1,971 & 887 & 5,689 & 3 & 224,817 \\
\hline 2007 & 1,985 & 879 & 5,742 & 2 & 204,127 \\
\hline 2008 & 1,898 & 834 & 5,649 & 1 & 201,664 \\
\hline 2009 & 2,223 & 966 & 6,607 & 2 & 177,882 \\
\hline 2010 & 2,296 & 1,006 & 6,926 & 1 & 196,699 \\
\hline 2011 & 2,309 & 1,007 & 7,009 & 1 & 195,532 \\
\hline 2012 & 2,498 & 1,073 & 7,704 & 4 & 228,078 \\
\hline 2013 & 2,529 & 1,045 & 8,584 & 3 & 347,191 \\
\hline
\end{tabular}

Source: Elaborated by the authors. 
Table 4 shows the descriptive statistics for the GDP variable by municipality between the years of 2004 and 2013. It is observed that the average value of the GDP variable grew, on average, 11.8\% p.y. in the period.

TABLE 4 DESCRIPTIVE STATISTICS OF THE ANNUAL MUNICIPAL GDP, CURRENT VALUES, IN R\$ THOUSAND

\begin{tabular}{|c|c|c|c|c|c|}
\hline Year & Average & Median & Standard deviation & Minimum & Maximum \\
\hline 2004 & $349,190.35$ & $48,198.13$ & $3,723,248.80$ & $3,183.93$ & $225,170,381.88$ \\
\hline 2005 & $385,916.48$ & $50,904.53$ & $4,237,693.56$ & $3,503.53$ & $261,455,917.21$ \\
\hline 2006 & $425,859.73$ & $56,963.78$ & $4,610,458.18$ & $3,746.16$ & $282,892,454.76$ \\
\hline 2007 & $483,619.24$ & $64,913.05$ & $5,240,545.80$ & $4,512.55$ & $323,154,665.88$ \\
\hline 2008 & $572,622.07$ & $74,416.66$ & $6,173,015.78$ & $6,492.19$ & $357,116,681.33$ \\
\hline 2009 & $582,103.15$ & $80,588.13$ & $6,346,376.79$ & $5,770.28$ & $389,317,166.69$ \\
\hline 2010 & $719,171.08$ & $93,296.52$ & $8,679,265.76$ & $7,237.63$ & $443,600,101.65$ \\
\hline 2011 & $747,384.80$ & $103,767.21$ & $7,806,938.17$ & $9,741.52$ & $477,005,597.21$ \\
\hline 2012 & $791,496.87$ & $109,785.52$ & $8,181,913.32$ & $8,342.57$ & $499,375,400.66$ \\
\hline 2013 & $954,810.11$ & $130,191.00$ & $9,504,351.70$ & $9,678.00$ & $570,706,192.00$ \\
\hline
\end{tabular}

Source: Elaborated by the authors.

Table 5 shows the descriptive statistics for the wages variable and other remunerations received by the total employed and salaried people per municipality between the years 2004 and 2013. It is observed that the average value of wages and other remunerations grew, on average, $14.3 \%$ p.y.

\section{TABLE 5 DESCRIPTIVE STATISTICS ON WAGES AND OTHER REMUNERATION, CURRENT VALUES, IN R\$ THOUSANDS}

\begin{tabular}{|c|c|c|c|c|c|}
\hline Year & Average & Median & Standard deviation & Minimum & Maximum \\
\hline 2004 & $71,641.06$ & $3,342.26$ & $1,101,459.89$ & - & $67,555,828.38$ \\
\hline 2005 & $81,569.35$ & $4,110.83$ & $1,232,143.08$ & - & $75,267,796.59$ \\
\hline 2006 & $98,407.89$ & $5,216.56$ & $1,471,465.41$ & 12.59 & $89,181,133.84$ \\
\hline 2007 & $110,887.61$ & $6,228.25$ & $1,636,708.62$ & 2.28 & $99,171,050.06$ \\
\hline 2008 & $128,854.13$ & $7,348.09$ & $1,893,471.47$ & 16.29 & $114,669,100.24$ \\
\hline 2009 & $143,927.64$ & 8,783.80 & $2,077,020.31$ & - & $124,377,680.04$ \\
\hline 2010 & $167,492.48$ & $10,260.29$ & $2,376,854.55$ & 47.70 & $142,150,179.34$ \\
\hline 2011 & $191,989.01$ & $12,049.54$ & $2,702,458.72$ & 96.66 & $161,769,713.10$ \\
\hline 2012 & $218,414.95$ & $13,972.78$ & $3,054,433.77$ & 8.03 & $182,963,919.90$ \\
\hline 2013 & $238,091.26$ & $16,038.26$ & $3,350,990.32$ & 29.50 & $201,301,606.08$ \\
\hline
\end{tabular}

Source: Elaborated by the authors. 
Table 6 shows the descriptive statistics for the total employed and salaried people variable by municipality between the years of 2004 and 2013. It is observed that the average value of employed and salaried people grew, on average, $4.9 \%$ p.y.

\section{TABLE 6 DESCRIPTIVE STATISTICS OF THE EMPLOYED AND SALARIED PEOPLE VARIABLE}

\begin{tabular}{|c|c|c|c|c|c|}
\hline Year & Average & Median & Standard deviation & Minimum & Maximum \\
\hline 2004 & 5,608 & 582 & 61,241 & - & $3,543,743$ \\
\hline 2005 & 5,956 & 630 & 64,552 & - & $3,731,795$ \\
\hline 2006 & 6,301 & 683 & 68,326 & 2 & $3,975,545$ \\
\hline 2007 & 6,776 & 732 & 73,570 & 4 & $4,277,939$ \\
\hline 2008 & 7,103 & 751 & 77,457 & 1 & $4,528,310$ \\
\hline 2009 & 7,442 & 830 & 79,913 & - & $4,654,681$ \\
\hline 2010 & 7,961 & 875 & 84,378 & 3 & $4,906,877$ \\
\hline 2011 & 8,368 & 921 & 88,157 & 6 & $5,098,791$ \\
\hline 2012 & 8,568 & 919 & 90,726 & 1 & $5,239,502$ \\
\hline 2013 & 8,598 & 970 & 89,971 & 3 & $5,281,006$ \\
\hline
\end{tabular}

Source: Elaborated by the authors.

Table 7 shows the descriptive statistics for local units of the municipality between the years 2004 and 2013. It is observed that the average value of the local units of the municipality decreased, on average, $0.1 \%$ p.y. in the period. There is also a decrease in local units in 2006, with recovery in the immediately following year.

\section{TABLE 7 DESCRIPTIVE STATISTICS OF THE LOCAL UNITS VARIABLE}

\begin{tabular}{|c|c|c|c|c|c|}
\hline Year & Average & Median & Standard deviation & Minimum & Maximum \\
\hline 2004 & 1,068 & 191 & 9,375 & 5 & 571,309 \\
\hline 2005 & 1,125 & 203 & 9,845 & 4 & 600,936 \\
\hline 2006 & 857 & 154 & 7,689 & 2 & 472,143 \\
\hline 2007 & 883 & 160 & 7,992 & 6 & 491,553 \\
\hline 2008 & 922 & 166 & 8,416 & 4 & 520,533 \\
\hline 2009 & 971 & 180 & 8,798 & 7 & 544,983 \\
\hline 2010 & 1,029 & 192 & 9,320 & 7 & 577,190 \\
\hline 2011 & 1,032 & 187 & 9,423 & 4 & 584,225 \\
\hline 2012 & 1,049 & 187 & 9,679 & 6 & 599,434 \\
\hline 2013 & 1,054 & 195 & 9,718 & 7 & 618,713 \\
\hline
\end{tabular}

Source: Elaborated by the authors. 
The obtained data may not present, when descriptively analyzed, normal distribution, exposing obliquity on one side when presenting the frequency distribution. This occurrence suggests some kind of transformation and the transformation used here is that of the Napierian logarithm.

Also, for a better quality of comparison of the current monetary values, their constant values are used. Thus, the implicit GDP deflator obtained from the IBGE, the Coordination of National Accounts Research Directorate and the National Consumer Price Index (INPC) is used for the other monetary amounts, also obtained in IBGE, according to Table 8.

\section{TABLE 8 IMPLICIT DEFLATOR OF GDP AND INPC BETWEEN 2004 AND 2013}

\begin{tabular}{|c|c|c|c|c|}
\hline \multirow{2}{*}{ Year } & \multicolumn{2}{|c|}{ Implicit GDP deflator } & \multicolumn{2}{|c|}{ INPC } \\
\hline & Percentage & Accumulated divider & Percentage & Accumulated divider \\
\hline 2004 & & 1.000 & & 1.000 \\
\hline 2005 & 0.0749 & 1.075 & 0.051 & 1.051 \\
\hline 2006 & 0.0669 & 1.147 & 0.028 & 1.080 \\
\hline 2007 & 0.0640 & 1.220 & 0.052 & 1.136 \\
\hline 2008 & 0.0887 & 1.328 & 0.065 & 1.209 \\
\hline 2009 & 0.0735 & 1.426 & 0.041 & 1.259 \\
\hline 2010 & 0.0857 & 1.548 & 0.065 & 1.341 \\
\hline 2011 & 0.0831 & 1.677 & 0.061 & 1.422 \\
\hline 2012 & 0.0587 & 1.775 & 0.062 & 1.510 \\
\hline 2013 & 0.0651 & 1.891 & 0.056 & 1.594 \\
\hline
\end{tabular}

Source: Elaborated by the authors.

\section{RESULTS}

This section presents, through the three models, first differences, fixed effects and Arellano-Bond, the results in the 2 hypotheses tested.

\subsection{Ordinary least squares}

The use of the OLS estimation method of the variables in the first difference (year by year) is a simple tool to deal with the bias problem generated by the omission of variables, once, assuming that the heterogeneity is constant in time, it will be withdrawn in the subtraction. One advantage of this model is that it removes the heterogeneity, regardless of the model, from fixed or random effects, in order 
to be the most appropriate one. Such a method causes the coefficients resulting from the OLS to be consistent and non-skewed. Likewise, $\Delta u_{i, t}{ }^{4}$ can be correlated in time, indicating that more advanced models must be used (Grene, 2008).

- Hypothesis H1: The PBF benefit is positively associated with the amount of salaried employees employed in the municipality.

Model 1:

$\ln \Delta$ salaried pop $=$

$=\beta_{\mathrm{o}}+\beta_{1} \ln \Delta$ local units $+\beta_{2} \ln \Delta \mathrm{GDP}+\beta_{3} \ln \Delta \mathrm{PBF}$ distributed value $+\mathrm{u}_{\mathrm{i}}$

Model 2:

$\ln \Delta$ salaried pop $=$

$=\beta_{\mathrm{o}}+\beta_{1} \ln \Delta$ local units $+\beta_{2} \ln \Delta \mathrm{GDP}+\beta_{3} \ln \Delta$ PBF beneficiaries $+\mathrm{u}_{\mathrm{i}}$

Table 9 presents the results of the PBF impact on salaried people from the municipality at constant values of 2004.

TABLE 9 IMPACT OF THE PBF ON SALARIED EMPLOYEES OF THE MUNICIPALITY, THE NAPIERIAN LOGARITHM OF THE VARIABLES IN THE FIRST DIFFERENCE, CONSTANT VALUES FOR 2004

$\begin{array}{lcc} & \text { Model } 1 & \text { Model } 2 \\ \text { Ln } \Delta \text { local units } & 0.4259^{\star \star \star} & 0.3929^{\star \star \star} \\ \text { Ln } \Delta \text { GDP of the municipality } & 0.2568^{\star \star \star} & 0.2947^{\star \star \star} \\ \text { Ln } \Delta \text { PBF distributed value } & 0.22149^{\star \star \star} & \\ \text { Ln } \Delta \text { PBF number of beneficiaries } & & 0.2033^{\star \star \star} \\ \text { Constant } & -3.1462^{\star \star \star} & -1.9495^{\star \star \star} \\ R^{2} & 0.47 & 0.48\end{array}$

Source: Elaborated by the authors.

Model 1 indicates that, considering controls as number of local municipal units and the GDP of the municipality, the total distributed PBF value is positively associated to the number of employed and salaried people in the municipality. The $1 \%$ increase in the difference of the value distributed between one year and another leads to an increase of $0.22 \%$ in the difference of salaried people in the municipality between 2 years.

${ }^{4} \Delta u_{i, t}$ means the first difference also applied to the random error. 
Model 2 shows that an 1\% increase in the difference of the beneficiaries between 2 years leads to an increase of $0.20 \%$ in the difference of the employed people between 2 years. The 2 models confirm the hypothesis.

- Hypothesis H2: The BPF benefit is positively associated with the total wages and other remunerations in the municipality.

Model 1:

$\ln \Delta$ total wages $=$

$=\beta_{\mathrm{o}}+\beta_{1} \ln \Delta$ salaried pop $+\beta_{2} \ln \Delta \mathrm{GDP}+\beta_{3} \ln \Delta \mathrm{PBF}$ distributed value $+\mathrm{u}$

Model 2:

$\ln \Delta$ total wages $=$

$=\beta_{\mathrm{o}}+\beta_{1} \ln \Delta$ salaried pop $+\beta_{2} \ln \Delta \mathrm{GDP}+\beta_{3} \ln \Delta$ PBF beneficiaries $+\mathrm{u}_{\mathrm{i}}$

Table 10 presents the results of the PBF impact on the municipal total salaries at constant values for 2004.

\section{TABLE 10 PBF IMPACT ON MUNICIPAL TOTAL SALARIES, NAPIERIAN LOGARITHM OF THE VARIABLES IN FIRST THE DIFFERENCE, CONSTANT VALUES OF 2004}

$\begin{array}{lcc} & \text { Model } 1 & \text { Model } 2 \\ \text { Ln } \Delta \text { salaried population } & 0.6614^{\star \star \star} & 0.6332^{\star \star \star} \\ \text { Ln } \Delta \text { GDP of the municipality } & 0.2009^{\star \star \star} & 0.2279^{\star \star \star} \\ \text { Ln } \Delta \text { PBF distributed value } & 0.1098^{\star \star \star} & \\ \text { Ln } \Delta \text { PBF number of beneficiaries } & & 0.1201^{\star \star \star} \\ \text { Constant } & 6.6526^{\star \star \star} & 7.1032^{\star \star \star} \\ \text { R2 } & 0.69 & 0.70\end{array}$

Source: Elaborated by the authors.

Model 1 indicates that the $1 \%$ increase in the difference between the 2 years in the PBF distributed value leads to an average increase of $0.11 \%$ in the total wage difference of the municipality. Model 2 indicates that the $1 \%$ increase in the difference between the 2 years in the number of PBF beneficiaries leads to an average increase of $0.12 \%$ in the total wage difference of the municipality. The 2 models confirm the hypothesis.

\subsection{Panel data models}

The second part of the statistical analysis presents the results of the panel data model, sets of data in which the same cross-sectional units are monitored over time. The Hausman (1978) test, for the 2 hypotheses, indicates the use of fixed effects model in detriment of the random effects model. 
- Hypothesis H1: The PBF benefit is positively associated with the amount of salaried employees employed in the municipality.

Model 1:

$$
\text { salaried pop }=\beta_{\mathrm{o}}+\beta_{1} \text { local units }+\beta_{2} \text { GDP }+\beta_{3} \text { PBF beneficiaries }+u_{i}
$$

Model 2:

$$
\text { salaried pop }=\beta_{\mathrm{o}}+\beta_{1} \text { local units }+\beta_{2} \mathrm{GDP}+\beta_{3} \mathrm{PBF} \text { distributed value }+\mathrm{u}_{\mathrm{i}}
$$

Table 11 presents the results of the PBF impact on the employed and salaried people from the municipality, at constant values of 2004.

\section{TABLE 11 PBF IMPACT ON THE EMPLOYED AND SALARIED PEOPLE FROM THE MUNICIPALITY, CONSTANT VALUES OF 2004}

$\begin{array}{lcc}\text { Independent Variables } & \text { Model } 1 & \text { Model } 2 \\ \text { Local units } & 4.91^{\star \star \star} & 4.49^{\star \star \star} \\ \text { GDP of the municipality } & 0.000000423 & 0.000000371 \\ \text { PBF beneficiaries } & 2.97^{\star \star \star} & \\ \text { PBF distributed value } & & 0.00272^{\star \star *} \\ \text { Constant } & -3,906.25 & -2,027.73^{\star \star}\end{array}$

Source: Elaborated by the authors.

Model 1 indicates that, when considering controls such as the municipal GDP and the number of local units in the municipality, an additional beneficiary of the PBF generates an increase of 2.97 salaried employed people in the municipality, with a significance of $99 \%$. Model 2 indicates that an increase of one monetary unit granted by the program entails an increase of 0.003 salaried person in the municipality, with a significance of $99 \%$. Therefore, both models confirm the hypothesis that PBF is positively associated with the number of salaried employees in the formal sector.

Hausman test. H0: no correlation between the regressors and the error term.

\section{TABLE 12 HAUSMAN TEST. HYPOTHESIS 1, MODEL 1}

\begin{tabular}{l|cccc} 
& EF & ER & EF-ER & SE \\
\hline Local units & 4.917 & 6.715 & -1.798 & 0.0319 \\
PBF beneficiaries & 2.972 & 2.663 & 0.309 & 0.0113 \\
GDP of the municipality & 0.000000423 & 0.000000566 & -0.000000143 \\
Chi $^{2}$ & 4548.06 & & \\
Prob>Chi & 0 & & \\
\hline
\end{tabular}

Source: Elaborated by the authors. 


\section{TABLE 13 HAUSMAN TEST. HYPOTHESIS 1, MODEL 2}

\begin{tabular}{ccccc} 
& EF & ER & EF-ER & SE \\
\hline Local units & 4.494 & 6.977 & -2.483 & 0.0331 \\
PBF distributed value & 0.0027 & 0.0026 & 0.0001 & 0.00000464 \\
GDP of the municipality & 0.000000371 & 0.000000501 & -0.00000013 \\
\hline Chi $^{2}$ & 6629.41 & & \\
Prob>Chi' & 0 & & \\
\end{tabular}

Source: Elaborated by the authors.

Table 12 presents the Hausman test of Hypothesis 1 for model 1, where EF stands for fixed effects, ER stands for random effects, EF-ER is the difference between both of them and SE is the standard error, and Table 13 presents the Hausman test of Hypothesis 1 for model 2. In both models, the Hausman test indicates that the null hypothesis must be rejected (Prob $>\mathrm{chi}^{2}<0,05$ ), because there is a correlation between the regressors and the error. Therefore, the fixed effects model must be used.

- Hypothesis H2: The BPF benefit is positively associated with the total wages and other remunerations in the municipality.

Model 1:

$$
\text { total wages }=\beta_{\mathrm{o}}+\beta_{1} \text { salaried pop }+\beta_{2} \mathrm{GDP}+\beta_{3} \text { PBF beneficiaries }+\mathrm{u}_{\mathrm{i}}
$$

Model 2:

$$
\text { total wages }=\beta_{\mathrm{o}}+\beta_{1} \text { salaried pop }+\beta_{2} \text { GDP }+\beta_{3} \text { PBF distributed value }+u_{i}
$$

Table 14 presents the results of the PBF impact on the municipal total salaries at constant values for 2004

TABLE 14 PBF IMPACT ON THE TOTAL MUNICIPAL WAGES, CONSTANT VALUES FOR 2004

$\begin{array}{lcc}\text { Independent variables } & \text { Model } 1 & \text { Model } 2 \\ \text { Salaried population } & 26,076.13^{\star \star \star} & 26,028.78^{\star \star *} \\ \text { GDP of the municipality } & 0.0115^{\star \star} & 0.0114^{\star * \star} \\ \text { PBF beneficiaries } & 16,448.24 \wedge & 12.5 \\ \text { PBF distributed value } & & -1,046,000,000^{\star * *} \\ \text { Constant } & -1,040,000,000^{\star \star \star} & \end{array}$

Source: Elaborated by the authors. 
Model 1 indicates that, controlling by the municipal GDP and the number of salaried people in the formal sector, the increase of a beneficiary of the PBF leads to an increase of approximately $\mathrm{R} \$$ $16,500.00$ in the total wages of the municipalities. However, the equation coefficient has lower security than generally accepted in Social Sciences works. Model 2 indicates a positive relation between the value distributed by the PBF and the total wages of the municipality. However, the coefficient is not statistically different from zero. Consequently, the above models demonstrate a positive relationship between the PBF and total wages, but it is not possible to fully accept Hypothesis 2 based on the above estimates.

Hausman test. H0: no correlation between the regressors and the error term.

\section{TABLE 15 HAUSMAN TEST. HYPOTHESIS 2, MODEL 1}

\begin{tabular}{lcccc} 
& EF & ER & EF-ER & SE \\
\hline Salaried population & 26028.78 & 20884.44 & -1.798 & 0.0319 \\
PBF distributed value & 0.0114 & 0.01274 & 0.309 & 0.0113 \\
GDP of the municipality & 12.5502 & 16.2723 & -0.000000143 \\
Chi $^{2}$ & 17326.12 & & \\
Prob>Chi2 & 0 & & \\
\hline
\end{tabular}

Source: Elaborated by the authors.

\section{TABLE 16 HAUSMAN TEST. HYPOTHESIS 2, MODEL 2}

\begin{tabular}{l|cccc} 
& EF & ER & EF-ER & SE \\
\hline Salaried population & 26028.78 & 20884.44 & -1.798 & 0.0319 \\
PBF distributed value & 0.0114 & 0.01274 & 0.309 & 0.0113 \\
GDP of the municipality & 12.5502 & 16.2723 & -0.000000143 \\
Chi $^{2}$ & 17326.12 & & \\
Prob>Chi & 0 & & \\
\end{tabular}

Source: Elaborated by the authors

Table 15 presents the Hausman test of Hypothesis 2 for model 1 and Table 16 presents the Hausman test of Hypothesis 2 for model 2. In both models, the Hausman test indicates that the null hypothesis must be rejected (Prob $>\mathrm{chi}^{2}<0,05$ ), because there is a correlation between the regressors and the error. Therefore, the fixed effects model must be used. 


\subsection{Arellano-Bond dynamic models}

The same two hypotheses of the study are tested with dynamic models, which include the dependent variable lagged as regressor and the dependent variables lagged in some periods. The decision to include the lagged dependent variable can be based on theoretical arguments since, if there is reason to assume that the current values of the dependent variables are highly dependent on the past values, the inclusion of this lag reduces the bias problem due to the omission of variables. In dynamic models of this kind, fixed or random effect models must not be used, once, by construction, the lagged dependent variable is correlated with the error. This endogeneity presence makes the estimators inconsistent. In this case, the Arellano-Bond estimation method is the most appropriate one. This estimator uses the generalized method of moments (GMM) and provides efficient estimators in a dynamic model.

- Hypothesis H1: The PBF benefit is positively associated with the amount of salaried employees employed in the municipality.

\section{Model 1:}

salaried pop $=\beta_{\mathrm{o}}+\beta_{1}$ salaried pop $_{\mathrm{t}-1}+\beta_{2}$ local units $_{\mathrm{t}}+\beta_{3}$ local units $_{\mathrm{t}-1}+\beta_{4}$ local units $_{\mathrm{t}-2}+$ $\beta_{5}$ GDP $_{\mathrm{t}}+\beta_{6} \mathrm{GDP}_{\mathrm{t}-1}+\beta_{7} \mathrm{GDP}_{\mathrm{t}-2}+\beta_{8}$ beneficiaries $_{\mathrm{t}}+\beta_{9}$ beneficiaries $_{\mathrm{t}-1}$

Model 2:

salaried pop $=\beta_{\mathrm{o}}+\beta_{1}$ salaried pop $_{\mathrm{t}-1}+\beta_{2}$ local units $_{\mathrm{t}}+\beta_{3}$ local units $_{\mathrm{t}-1}+\beta_{4}$ local units $_{\mathrm{t}-2}+$

$\beta_{5} \mathrm{GDP}_{\mathrm{t}}+\beta_{6} \mathrm{GDP}_{\mathrm{t}-1}+\beta_{7} \mathrm{GDP}_{\mathrm{t}-2}+\beta_{8}$ distributed value $_{\mathrm{t}}+\beta_{9}$ distributed value $_{\mathrm{t}-1}+$ $\beta_{10}$ distributed value $_{\mathrm{t}-2}+\mathrm{u}_{\mathrm{i}}$

Table 17 presents 2 dynamic models for the Hypothesis 1 test of this study.

\section{TABLE 17}

PBF IMPACT ON THE EMPLOYED AND SALARIED PEOPLE FROM THE MUNICIPALITY, CONSTANT VALUES OF 2004, BY ARELLANO-BOND DYNAMIC MODEL

$\begin{array}{lcc}\text { Salaried population } & \text { Model } 1 & \text { Model } 2 \\ \text { L1 } & & \\ \text { Local units } & 0.21^{\star \star \star} & 0.17^{\star \star \star} \\ \text { L1 } & 7.85^{\star \star \star} & 7.79^{\star \star \star} \\ \text { L2 } & 0.27 & -0.49 \\ \text { GDP of the municipality } & 0.24 & -0.049 \\ \text { L1 } & -0.000000141 & -0.0000000119 \\ \text { L2 } & -0.00000000959 & 0.00000000217 \\ \text { PBF beneficiaries } & 0.000000145^{\star} & 0.000000166^{\star} \\ \text { L1 } & 0.29 & \\ \text { L2 } & 0.19 & \\ \text { PBF distributed value } & 0.56^{\star \star \star} & 0.0003^{\star \star \star} \\ \text { L1 } & & 0.0002 \\ \text { L2 } & & 0.0006^{\star}\end{array}$

Source: Elaborated by the authors. 
The abbreviation L1 indicates that the variable was lagged in one period, while L2 indicates that the variable was lagged in 2 periods. The models show that there is a lagged effect on the response: in both models, the coefficients of the PBF beneficiaries and PBF total distributed values variables are significant and have a greater magnitude when they are out of date in 2 years.

Robustness test. H0: There is no errors autocorrelation in the first difference.

\section{TABLE 18 ERRORS AUTOCORRELATION TEST OF THE FIRST DIFFERENCE IN HYPOTHESIS 1}

\begin{tabular}{ccc} 
& Model 1 & Model 2 \\
\hline Prob $>$ z & 0.024 & 0.0203
\end{tabular}

Source: Elaborated by the authors.

Table 18 shows the errors autocorrelation test in the first difference. H0 must be rejected. Thus, there is evidence that the Arellano-Bond model assumptions are respected.

- Hypothesis H2: The BPF benefit is positively associated with the total wages and other remunerations in the municipality.

Model 1:

$$
\begin{gathered}
\text { total salaried }=\beta_{\mathrm{o}}+\beta_{1} \text { total salaried }_{\mathrm{t}-1}+\beta_{2} \text { local units }_{\mathrm{t}}+\beta_{3} \text { local units }_{\mathrm{t}-1}+\beta_{4} \text { local } \\
\text { units }_{\mathrm{t}-2}+\beta_{5} \mathrm{GDP}_{\mathrm{t}}+\beta_{6} \mathrm{GDP}_{\mathrm{t}-1}+\beta_{7} \mathrm{GDP}_{\mathrm{t}-2}+\beta_{8} \text { beneficiaries }_{\mathrm{t}}+\beta_{9} \text { beneficiaries }_{\mathrm{t}-1}+ \\
\beta_{10} \text { beneficiaries }_{\mathrm{t}-2}+\mathrm{u}_{\mathrm{i}}
\end{gathered}
$$

Model 2:

total salaried $=\beta_{\mathrm{o}}+\beta_{1}$ total salaried $_{\mathrm{t}-1}+\beta_{2}$ local units $_{\mathrm{t}}+\beta_{3}$ local units $_{\mathrm{t}-1}+\beta_{4}$ local units $_{\mathrm{t}-2}+\beta_{5} \mathrm{GDP}_{\mathrm{t}}+\beta_{6} \mathrm{GDP}_{\mathrm{t}-1}+\beta_{7} \mathrm{GDP}_{\mathrm{t}-2}+\beta_{8}$ distributed value $_{\mathrm{t}}+\beta_{9}$ distributed value $_{\mathrm{t}-1}+\beta_{10}$ distributed value $_{\mathrm{t}-2}+\mathrm{u}_{\mathrm{i}}$

Table 19 presents the results of the PBF impact on the municipal total salaries at constant values for 2004 .

\begin{tabular}{|c|c|c|}
\hline & Model 1 & Model 2 \\
\hline Total wages & - & - \\
\hline L1 & $0.57^{\star \star \star}$ & $0.55^{\star \star \star}$ \\
\hline Local units & $116,956.4^{\star \star \star}$ & $116,757.3^{\star \star \star}$ \\
\hline
\end{tabular}

\section{TABLE 19 PBF IMPACT ON THE TOTAL MUNICIPAL WAGES, CONSTANT VALUES FOR 2004, BY ARELLANO-BOND DYNAMIC MODEL}




$\begin{array}{lcc} & \text { Model } 1 & \text { Model } 2 \\ \text { L1 } & 29,356.79^{\star \star \star} & 29,450.9^{\star \star \star} \\ \text { L2 } & 2,807.45^{\star \star \star} & -4,693.75 \\ \text { GDP of the municipality } & & 0.0012 \\ \text { L1 } & 0.0016 & 0.0008 \\ \text { L2 } & 0.004^{\star \star} & 0.0048^{\star \star} \\ \text { PBF beneficiaries } & 7,342.5^{\star \star \star} & \\ \text { L1 } & 7,137.21^{\star \star} & \\ \text { L2 } & 11,790.01^{\star \star \star} & \\ \text { PBF distributed value } & & -14.43^{\star \star \star} \\ \text { L1 } & & -4.78 \\ \text { L2 } & & \end{array}$

Source: Elaborated by the authors.

Model 1 also indicates the dynamic character of the impact of the PBF beneficiaries number and the total formal wages of the municipality. The coefficient of the explanatory lagged variable in two years indicates that the increase of a PBF beneficiary leads, on average, to an increase of $\mathrm{R} \$ 11,790.01$ in the total wage of the municipality. The coefficients remain positive and significant for the level variable. For the variable lagged in one year, however, the impact is reduced to $\mathrm{R} \$ 7,137.21$. In model 2, the dynamic effect does not appear. Only the coefficient of the level variable is significant and indicates that an increase of $\mathrm{R} \$ 1.00$ in the PBF total value distributed leads to an increase of $\mathrm{R} \$ 14.00$ in the total formal wages of the municipalities. In conclusion, the robustness test also indicates that there is an evidence that the Arellano-Bond model assumptions are respected.

Robustness test. H0: There is no errors autocorrelation in the first difference.

\section{TABLE 20 ERRORS AUTOCORRELATION TEST OF THE FIRST DIFFERENCE IN HYPOTHESIS 2}

\begin{tabular}{|ccc} 
& Model 1 & Model 2 \\
\hline Prob $>z$ & 0.0084 & 0.0053
\end{tabular}

Source: Elaborated by the authors.

Table 20 presents the results of the autocorrelation test of the first difference errors. H0 must be rejected. Thus, there is evidence that the Arellano-Bond model assumptions are respected. 


\section{FINAL CONSIDERATIONS}

According to the results obtained, the three models used (first differences, fixed effects, and ArellanoBond) indicate the positive association of the municipality PBF benefits with salaried people and with wages and other income in the municipality.

From the academic point of view, it is understood as contribution that, by using the total specific data of each one of the Union municipalities instead of basing itself on the data from PNAD or IBGE Census, this research allows the confrontation with the conclusions of previous studies, developed through the use of alternative data bases. For that matter, the result presented herein corroborates previous results, obtained with alternative bases, which indicate the positive association of PBF with the labor market.

A second academic contribution is the application of the three econometric models, Napierian logarithms of the first differences, fixed-effects panel data model and Arellano-Bond dynamic panel data model, whose convergence of results solidifies the research.

From the public policy management point of view, it is understood as real and effective contribution the finding that the PBF is positively associated to the formal labor market of the Brazilian municipalities, both regarding the increase in salaried employed people and the increase in wages and other incomes. Such results reinforce previous studies that suggested that the transfers of income from the PBF can cause salary increases in a new market balance of the municipality. The finding that the results indicate that the PBF benefit does not cause adverse effects regarding the decisions related to the labor supply is added to the previous contribution.

Thus, the expectation of maintaining this cash conditional transfer program is preserved, both as a generator of social benefits, characterized by the fight against absolute poverty, improvement in education, health and fight against family hunger, and as an endogenous factor contributing to the growth of salaried employees and to wages and other income in the municipality.

Some limitations of this research must be mentioned. A first limitation refers to the nonconsideration of the municipality worker association with his/her address, since the data related to the individual may be allocated, regarding the PBF benefit, in a municipality and, as a person formally employed, in a different municipality. A second limitation is that the research only deals with a formal work, since the source used only offers this data. Thus, the substitution effect, derived from the informal work, is not considered.

Finally, some suggestions may be offered for the continuity of this study: a) research using data from 2014 and 2016, which incorporate a new trend of the unemployment rate; b) research encompassing the individual analysis of the municipalities, in order to observe in which municipal environments there is a greater adherence to the presented results; and c) research of possible characteristics in the set of municipalities where the positive association is more latent. 


\section{REFERENCES}

Alzúa, M. L., Cruces, G., \& Ripani, L. (2012). Welfare programs and labor supply in developing countries: experimental evidence from Latin America. Journal of Population Economics, 26(4), 1255-1284.

Arellano, M., \& Bond, S. (1991). Some tests of specification for panel data: Monte Carlo evidence and an application to employment equations. Review of Economic Studies, 58, 277-297.

Arretche, M. (1995). Emergência e desenvolvimento do welfare state: teorias explicativas. Revista Brasileira de Informação Bibliográfica em Ciências Sociais, 39, 3-40.

Asfaw, S., Davis, B., Dewbre, J., Handa, S., \& Winters, P. (2014). Cash transfer programme, productive activities and labour supply: evidence from randomized experiment in Kenya. Journal of Development Studies, 50(8), 1172-1196.

Barbosa, A. L. N. H., \& Corseuil, C. H. L. (2014, April). Bolsa Família, escolha ocupacional e informalidade no Brasil (Texto para Discussão IPEA n. 1948). Retrieved from http://repositorio.ipea.gov. br/bitstream/11058/3026/1/TD_1948.pdf

Barro, R. J. (1990). Government spending in a simple model of endogeneous growth. Journal of Political Economy, 98 (S5).

Barro, R. J. (1991, May). Economic Growth in a Cross Section of Countries. The Quarterly Journal of Economics, 106(2), 407-443.

Brito, A., \& Kerstenetzky, C. L. (2010). Programa Bolsa Família e mercado de trabalho: considerações metodológicas e substantivas. In Anais do 380 Encontro Nacional de Economia, Salvador, BA.

Bussmann, T. B., \& Risco, G. R. M. (2012). Mensuração da desigualdade e do crescimento no estado de Minas Gerais: estimação da curva de Kuznets. In Anais do 15o Seminário sobre a Economia Mineira, Diamantina, MG.

Cavalcanti, D. M., Costa, E. M., Silva, J. L. M., \& Sampaio, R. M. B. (2016). Impactos do Programa Bolsa Família na renda e na oferta de trabalho das famílias pobres: uma abordagem usando o efeito quantílico de tratamento. Economia Aplicada, 20(2), 173-201.

Cavalcanti, T., \& Corrêa, M. (2010). Cash transfers and the labor market. Revista Brasileira de Economia, 64(2), 175-190.
Constituição da República Federativa do Brasil, de 5 de outubro de 1988. (1988). Brasília, DF.

Denes, G., Komatsu, B. K., \& Menezes, N., Filho. (2016, August). Uma avaliação dos impactos macroeconômicos e sociais de programas de transferência de renda nos municípios brasileiros (Policy Paper Insper n. 21). Retrieved from https:// www.insper.edu.br/wp-content/uploads/2018/09/ Avaliacao-Impactos-Macroeconomicos-SociaisTransferencia-Renda-Municipios-Brasileiros.pdf

Draibe, S. M. (2009). Programas de transferências condicionadas de renda. In F. H. Cardoso, A. Alejandro (Eds.), América Latina: desafios da democracia e do desenvolvimento - políticas sociais para além da crise. Rio de Janeiro, RJ: Campus.

Easterly, W., \& Rebelo, S. (1993). Fiscal policy and economic growth: an empirical investigation. Journal of Monetary Economics, 32, 417-458.

Economic Commission for Latin America and the Caribbean, \& International Labour Organization. (2015, May). Employment situation in Latin America and the Caribbean (Number 12). Retrieved from https://repositorio.cepal.org/bitstream/ handle/11362/38053/1/S1500310_en.pdf

Fleury, S. (1994). Estado sem cidadãos: seguridade social na América Latina. Rio de Janeiro, RJ: Fundação Oswaldo Cruz.

Foguel, M. N., \& Barros, R. P. (2010). The effects of conditional cash transfer programmes on adult labour supply: an empirical analysis using a time-series-cross-section sample of Brazilian municipalities. Estudos Econômicos, 40(2), 259-293.

Grene, W. H. (2008). Econometric analysis. Upper Saddle River, NJ: Pearson Prentice Hall.

Hausman, J. A. (1978, November). Specification Test in Econometrics. Econometrica, 46(6), 1251-1271.

Jacinto, P. A., \& Tejada, C. A. O. (2009). Desigualdade de renda e crescimento econômico nos municípios da região Nordeste do Brasil: o que os dados têm a dizer? Revista Econômica do Nordeste, 40(1), 61-80.

Kabber, N., \& Waddington, H. (2015). Economic impacts of conditional cash transfer programmes: a systematic review and meta-analysis. Journal of Development Effectiveness, 7(3), 290-303.

Kerstenetzky, C. L. (2011). Welfare state e desenvolvimento. Dados: Revista de Ciências Sociais, 54(1), 129-156. 
King, G., Keohane, R. O., \& Verba, S. (1996). Designing social inquiry: scientific inference in qualitative research. Princeton, NJ: Princeton University Press.

Lucas, R. E., Jr. (1988). On the mechanics of economic development. Journal of Monetary Economics, 22, 3-42.

Marinho, E., \& Mendes, S. (2013). The impact of government income transfers on the Brazilian job market. Estudos Econômicos, 43(1), 29-50.

Nunes, J. A., \& Mariano, J. L. (2015). Efeitos dos programas de transferência de renda sobre a oferta de trabalho não agrícola na área rural da região Nordeste. Revista de Economia e Sociologia Rural, 53(1), 71-90.

Okun, A. M. (1975). Equality and efficiency: the big tradeoff. Washington, DC: Brookings Institution Press.

Oliveira, L. F. B., \& Soares, S. S. D. (2012, May). $O$ que se sabe sobre os efeitos das transferências de renda sobre a oferta de trabalho (Texto para Discussão IPEA n. 1738). Retrieved from http:// www.ipea.gov.br/portal/index.php?option=com content\&view $=$ article\&id $=15785$

Pontusson, J. (2005). Inequality and prosperity: social Europe vs. liberal America. New York, NY: Cornell University Press.
Rands Barros, A., \& Athias, D. (2013). Salário mínimo, Bolsa Família e desempenho relativo recente da economia do Nordeste. Revista de Economia Política, 33(1), 179-199.

Ribas, R., \& Soares, F. (2011, March 9). Is the effect of conditional transfers on labor supply negligible everywhere? Retrieved from http://conference.iza. org/conference_files/worldb2011/ribas_r6802.pdf

Romer, P. M. (1986). Increasing returns and longrun growth. The Journal of Political Economy, 94(5), 1002-1037.

Santos, D. B., Leichsenring, A. R., Menezes, N., Filho, \& Mendes-da-Silva, W. (2017). Os efeitos do Programa Bolsa Família sobre a duração do emprego formal dos indivíduos de baixa renda. Revista de Administração Pública, 51(5), 708-733.

Skoufias, E., \& Di Maro, V. (2008). Conditional cash transfers, adult work incentives, and poverty. The Journal of Development Studies, 44(7): 935-960.

Soares, S., \& Sátyro, N. (2009). O Programa Bolsa Família: desenho institucional, impactos e possibilidades futuras. Brasília, DF: Instituto de Pesquisa Econômica Aplicada.

Tavares, P. A. (2010). Efeito do Programa Bolsa Família sobre a oferta de trabalho das mães. Economia e Sociedade, 19(3), 613-635.

\section{Carlos Barbosa Correa Junior}

https://orcid.org/0000-0002-3614-2153

$\mathrm{PhD}$ in Administration by the Post-Graduate Studies Program in Administration at Pontifical Catholic University of São Paulo (PUC-SP). E-mail: carlosbcj5454@gmail.com

\section{Leonardo Nelmi Trevisan}

https://orcid.org/0000-0002-0914-3679

$\mathrm{PhD}$ in Political Science by the Post-Graduate Studies Program in Administration at Pontifical Catholic University of São Paulo (PUC-SP). E-mail: lntrevisan@pucsp.br

\section{Cristina Helena Pinto de Mello}

https://orcid.org/0000-0002-2002-0645

$\mathrm{PhD}$ in Economics by the Master Program in Consumer Behavior at Superior School of Advertising and Marketing (ESPM). E-mail: chmellop@gmail.com 